\title{
Analisis Perlakuan Akuntansi Aset Tetap pada Badan Pengelolaan Keuangan Daerah (BPKD)
}

\author{
Baso $\mathbf{R}^{\varpi_{1}}$, Selfiana Bintari², \& Sumarni $\mathbf{S}^{3}$ \\ ${ }^{1}$ Sekolah Tinggi Ilmu Ekonomi Makassar \\ 2,3 Sekolah Tinggi Ilmu Ekonomi (STIE) Wira Bhakti Makassar \\ DOI : https://doi.org/10.37531/ecotal.v1i1.6
}

\begin{abstract}
ABSTRAK
Tujuan penelitian ini adalah untuk mengetahui dan menganalisis perlakuan akuntansi aset tetap pada Badan Pengelolaan Keuangan Daerah (BPKD) yang tercantum dalam Peraturan Bupati Nomor 19 Tahun 2019. Metode analisis dalam penelitian ini adalah dekskriptif kuantitatif. Obyek penelitian Badan Pengelolaan Keuangan Daerah (BPKD). Hasil penelitian menujukkan bahwa perlakuan akuntansi aset tetap pada Badan Pengelolaan Keuangan Daerah (BPKD) berpedoman pada Peraturan Pemerintah Nomor 71 Tahun 2010 serta Peraturan Bupati Nomor 19 Tahun 2019. Artinya bahwa semua perlakuan aset tetap yang diterapkan sesuai dengan peraturan perundang-undangan yang berlaku. Aset tetap yang tercantum di dalam Neraca Badan Pengelolaan Keuangan Daerah (BPKD) pada tahun 2015 sampai dengan tahun 2019 sudah sesuai dengan Standar Akuntansi Pemerintah (PSAP No. 07 tentang Akuntansi Aset Tetap) masingmasing aset tetap diungkapkan dalam laporan keuangan Badan Pengelolaan Keuangan Daerah (BPKD) menggunakan aplikasi SIMDA.
\end{abstract}

\section{Keywords:}

Perlakuan Akuntansi, Aset Tetap, BPKD

Abstract : The purpose of this study was to determine and analyze the accounting treatment of fixed assets at the Regional Financial Management Agency (BPKD) listed in Regent Regulation Number 19 of 2019. The method of analysis in this study is quantitative descriptive. The research object of the Regional Financial Management Agency (BPKD). The results of the study show that the fixed asset accounting treatment at the Regional Financial Management Agency (BPKD) is guided by Government Regulation Number 71 of 2010 and Regent Regulation Number 19 of 2019. This means that all fixed asset treatments are applied in accordance with applicable laws and regulations. Fixed assets listed in the Regional Financial Management Agency (BPKD) Balance Sheet from 2015 to 2019 are in accordance with Government Accounting Standards (PSAP No. 07 concerning Fixed Asset Accounting), each fixed asset is disclosed in the financial statements of the Regional Financial Management Agency (RFMA) using the SIMDA application. Keywords : Accounting Treatment, Fixed Assets, RFMA

\footnotetext{
$\triangle$ Corresponding Author :

E-mail address: baso.r@yahoo.co,id. (Pettarani, Tamamaung, Panakkukang, Sulawesi Selatan)

“Received 03 January 2020, Accepted 15 January 2020, Published 29 January 2020"
} 
Baso $\mathbf{R}^{\otimes_{1}}$, Selfiana Bintari'2, \& Sumarni $\mathbf{S}^{3}$

Analisis Perlakuan Akuntansi Aset Tetap pada Badan Pengelolaan Keuangan Daerah (BPKD)

DOI : https://doi.org/10.37531/ecotal.v1i1.6

\section{Pendahuluan}

Aset Pemerintah Daerah merupakan salah satu elemen dari neraca pemerintah daerah. Informasi aset dalam laporan neraca menggambarkan kondisi kekayaan ekonomi yang dimiliki pemerintah daerah. Melalui informasi aset yang disajikan dalam neraca, pembaca laporan keuangan dapat melihat bahwa pemerintah A secara ekonomi relatif lebih kaya dibandingkan pemerintah B. Kondisi kekayaan pemerintah daerah disimbolkan dalam neraca berupa aset lancar, investasi jangka panjang, dana cadangan, aset tetap, dan aset lainnya yang dimiliki. Analisis aset pemerintah daerah dilakukan untuk mengetahui secara lebih dalam tentang kekayaan dan potensi ekonomi pemerintah daerah sehingga dari informasi tersebut masyarakat dapat menilai berbagai hal, misalnya seberapa menarik melakukan investasi di wilayah itu terkait dengan keamanan berinvestasi serta potensi keuntungan yang bisa didapat seberapa nyaman tinggal di daerah tersebut terkait dengan kelengkapan sarana dan prasarana publik, seberapa besar kemandirian keuangan pemerintah daerah, seberapa besar potensi kerjasama kemitraan dengan pemerintah daerah, dan sebagainya. (Mahmudi, 2016)

Dalam laporan keuangan, aset tetap merupakan golongan aset yang mempunyai nilai yang cukup besar. Pengelolaan aset tetap instansi pemerintah diatur dalam Pernyataan Standar Akuntansi Pemerintahan No. 07 tentang Akuntansi Aset Tetap dan Pernyataan Standar Akuntansi Pemerintahan No. 08 tentang Konstruksi Dalam Pengerjaan (Sita, dkk 2017). Aset tetap merupakan aset berwujud yang mempunyai masa manfaat lebih dari 12 (dua belas) bulan untuk digunakan, atau dimaksudkan untuk digunakan, dalam kegiatan pemerintah atau dimanfaatkan oleh masyarakat umum (Standar Akuntansi Pemerintahan Pernyataan No. 07) (Tipan, 2015).

Proses pencatatan serta penyajian aset tetap harus sesuai dengan standar akuntansi keuangan yang berlaku sekarang, agar tidak terjadi kesalahan penyajian material yang berdampak pada ketidakakuratan informasi yang tersaji dan mempengaruhi atau menyesatkan keputusan pengguna laporan keuangan, maka perlakuan akuntansi aset tetap tersebut sangat besar pengaruhnya terhadap laporan keuangan instansi/perusahaan. Aset Tetap dalam Pernyataan Standar Akuntansi Pemerintahan (PSAP) No.07 merupakan aset berwujud yang mempunyai masa manfaat lebih dari 12 (dua belas) bulan untuk digunakan, atau dimaksudkan dalam kegiatan pemerintah atau dimanfaatkan oleh masyarakat umum (IAI PSAP 07:1).

Volume 1 Issue 1 (2020)

Economics and Digital Business Review

ISSN: 2774-2563 (Online) 
Baso $\mathbf{R}^{\otimes_{1}}$, Selfiana Bintari'2, \& Sumarni $\mathbf{S}^{3}$

Analisis Perlakuan Akuntansi Aset Tetap pada Badan Pengelolaan Keuangan Daerah (BPKD)

DOI : https://doi.org/10.37531/ecotal.v1i1.6

Badan Pengelolaan Keuangan Daerah (BPKD) merupakan unit kerja pada suatu pemerintahan kabupaten/kota yang ada di wilayah Pemerintahan Kabupaten Gowa yang mempunyai tugas antara lain memegang peranan dan fungsi startegis di bidang Pengelolaan Keuangan Daerah yang dibentuk berdasarkan Peraturan Pemerintah Nomor 18 Tahun 2016 tentang Perangkat Daerah dan Peraturan Daerah Nomor 11 Tahun 2016 tentang Pembentukan dan Susunan Perangkat Daerah, serta Peraturan Bupati Gowa Nomor 68 Tahun 2016 tentang Susunan Organisasi, Kedudukan, Tugas dan Fungsi, serta Tata Kerja Badan Pengelolaan Keuangan Daerah (BPKD) Kabupaten Gowa. Badan Pengelolaan Keuangan Daerah (BPKD) Kabupaten Gowa memiliki aset tetap sebesar Rp.4.489.466.360 pada tahun 2019 (BPKD, 2019).

Perlakuan akuntansi untuk aset tetap meliputi pengakuan, pengukuran, pengungkapan, prosedur akuntansi aset tetap dan konstruksi dalam pengerjaan. Pernyataan-pernyataan dalam PSAK No.16 Tahun 2015 harus diterapkan dalam perlakuan akuntansi aset tetap kecuali ada pernyataan lain yang menetapkan atau mengizinkan perlakuan akuntansi yang berbeda dengan standar ini. Di dalam PSAK No.16 tahun 2015 yang dimaksud dengan aset tetap adalah aktiva berwujud yang dimiliki untuk digunakan dalam produksi atau penyediaan barang dan jasa untuk direntalkan kepada pihak lain, atau untuk tujuan administratif diharapkan digunakan selama lebih dari satu periode (IAI, 2015).

Perlakuan akuntansi aset tetap telah diteliti oleh peneliti sebelumnya diantaranya (Rusman, 2018) yang meneliti tentang perlakuan aset tetap pada pemerintahan Aceh hasilnya menunjukkan bahwa perlakuan aset tetap pada pemerintah Aceh dengan studi pada dinas pendapatan dan kekayaan Aceh pada umumnya telah dilaksanakan sebagaimana yang dimaksud Standar Akuntansi Pemerintahan menurut peraturan pemerintah No. 71 tahun 2010. (Safitri dan Rahayu, 2017) yang meneliti tentang perlakuan akuntansi tetap berdasarkan PSAP No. 07 hasilnya menunjukkan bahwa perlakuan akuntansi aset tetap pada dinas pertanian dan ketahanan pangan provinsi Jawa Timur yang meliputi pengakuan, pengakhiran dan pelepasan, serta pengungkapan pada periode 2011-2014 telah sesuai dengan ketentuan pernyataan standar akuntansi pemerintahan (PSAP) No. 07. 


\section{Kajian Literatur}

\subsection{Pengertian Akuntansi Pemerintahan}

Akuntansi adalah suatu proses mencatat, meringkas, mengklasifikasi, mengolah dan menyajikan data transaksi,serta berbagai aktifitas yang terkait dengan keuangan. (Warren, James, dkk., 2018) mendefinisikan akuntansi adalah system informasi yang menyediakan laporan untuk para pemangku kepentingan mengenai aktivitas ekonomi dan kondisi perusahaan. (Kieso, Donald dkk 2018:4) menyatakan bahwa akuntansi terdiri dari tiga kegiatan yang mendasar yaitu identifikasi, pencatatan dan pengkomunikasian peristiwa ekonomi suatu organisasi kepada pihak yang berkepentingan.

\subsection{Aset tetap}

Aset tetap adalah aset berwujud yang digunakan untuk penyediaan barang atau jasa, disewakan kepada pihak lain atau untuk tujuan administratif dan diharapkan untuk digunakan selama lebih dari satu periode (IAI, 2017:06). Pernyataan Standar Akuntansi Pemerintahan (PSAP) yang mengatur tentang akuntansi aset adalah PSAP Nomor 07. PSAP Nomor 7 mendefinisikan, standar akuntansi pemerintahan adalah prinsip-prinsip akuntansi yang diterapkan dalam menyusun dan menyajikan laporan keuangan pemerintah (Rusmana, Setyaningrum, dkk, 2017:32).

Aset tetap menurut Pernyataan Standar Akuntansi Pemerintahan (PSAP) No. 7 Paragraf 4 aset berwujud yang mempunyai masa manfaat lebih dari 12 (dua belas) bulan untuk digunakan, dalam kegiatan pemerintah atau dimanfaatkan oleh masyarakat umum. Salah satu kriteria dari aset yanf dapat dikategorikan sebagai aset tetap adalah nilainya yang besar. Aset tetap yang nilai per unitnya kecil dapat langsung dikelompokkan sebagai persediaan. (Erlina, dkk 2017:245). Termasuk dalam aset tetap pemerintah adalah aset tetap yang dimiliki oleh entitas pelaporan, namun dimanfaatkan oleh entitas lainnya, misalnya instansi pemerintah lainnya, universitas, dan kontraktor dan Hak atas Tanah, tidak termasuk dalam defenisi aset tetap adalah aset yang dikuasai untuk dikomsumsi dalam operasi pemerintah, seperti bahan (materials) dan perlengkapan (supplies). 
Baso $\mathbf{R}^{\otimes_{1}}$, Selfiana Bintari², \& Sumarni $\mathbf{S}^{3}$

Analisis Perlakuan Akuntansi Aset Tetap pada Badan Pengelolaan Keuangan Daerah (BPKD)

DOI : https://doi.org/10.37531/ecotal.v1i1.6

\subsection{Prosedur Akuntansi Aset Tetap}

Dalam Permendagri No.20 Tahun 2009 menjelaskan bahwa prosedur akuntansi aset pada SKPD mencakup pencatatan dan pelaporan akuntansi atas perolehan, pemeliharaan, rehabilitasi, perubahan klasifikasi, dan penyusutan terhadap aset tetap yang dikuasai/digunakan SKPD. Transaksi-transaksi tersebut secara garis besar digolongkan dalam 2 kelompok besar transaksi, yaitu: Penambahan nilai asset dan pengurangan nilai aset. Pencatatan aset dimulai dengan adanya bukti transaksi yang berupa berita acara penerimaan barang, berita acara serah terima barang dan berita acara penyelesaian pekerjaan. Berdasarkan bukti tersebut, PPK-SKPD membuat bukti memorial. Bukti memorial tersebut dapat dikembangkan dalam format yang sesuain dengan kebutuhan yang sekurang-kurangnya memuat informasi mengenai : Jenis/nama aset tetap, kode rekening yang terkait, klasifikasi aset tetap, nilai aset tetap, tanggal transaksi.

Pada bagian belanja langsung (LS) khususnya untuk belanja modal, selain mempengaruhi laporan realisasi anggaran juga akan mempengaruhi neraca. Untuk itu perlu dilakukan pencatatan penambahan nilai aset berdasarkan bukti memorial tersebut, seperti saat PPK-SKPD mengakui penambahan aset. Pembelian aset tetap tidak mempengaruhi komponen-komponen perkiraan dalam laporan operasional.

\subsection{Pengungkapan Aset Tetap}

Pernyataan Standar Akuntansi Pemerintahan (PSAP) Nomor 7 paragraf 80-81, laporan keuangan harus mengungkapkan untuk masing-masing jenis aset tetap sebagai berikut yaitu dasar penilaian yang digunakan untuk menentukan nilai tercatat (carring amount), rekonsiliasi jumlah tercatat pada awal dan akhir periode yang menunjukkan penambahan; akumulasi penyusutan dan perubahan nilai, jika ada; atau mutasi aset lainnya, Informasi penyusutan, meliputi nilai penyusutan; metode penyusutan yang digunakan; manfaat atau tarif penyusutan yang digunakan; nilai tercatat bruto dan akumulasi penyusutan pada awal dan akhir periode. Eksistensi dan batasan hak milik atas aset tetap kebijakan akuntansi untuk kapitalisasi yang berkaitan dengan aset tetap. Jumlah pengeluaran pada pos aset tetap dalam konstruksi. Jumlah komitmen untuk akuisisi aset tetap. Terkait dengan konstruksi dalam pengerjaan, PSAP Nomor 8 paragraf 34 menyebut suatu entitas harus mengungkapkan informasi mengenai kontruksi dalam pengerjaan pada akhir periode akuntansi dengan melampirkan rincian kontrak kontruksi dalam pengerjaan berikut tingkat penyelesaian dan jangka waktu penyelesaiannya, nilai kontrak 
Baso $\mathbf{R}^{\otimes_{1}}$, Selfiana Bintari², \& Sumarni $\mathbf{S}^{3}$

Analisis Perlakuan Akuntansi Aset Tetap pada Badan Pengelolaan Keuangan Daerah (BPKD)

DOI : https://doi.org/10.37531/ecotal.v1i1.6

konstruksi dan sumber pendanaannya, jumlah biaya yang telah dikeluarkan dan masih harus dibayar, uang muka kerja yang diberikan dan Retensi (Erlina, 2017:279).

\section{Metode Penelitian}

Tempat penelitian dilakukan pada Badan Pengelolaan Keuangan Daerah (BPKD) Kabupaten Gowa yang beralamat Jl. Mesjid Raya No.30 Sungguminasa, Kabupaten Gowa. Waktu penelitian selama 2 bulan yaitu mulai bulan Agustus sampai dengan September Tahun 2020. Metode pengumpulan data yang dipakai dalam penelitian ini adalah dokumentasi. Menurut (Usman, 2017:106) teknik pengumpulan data dengan dokumentasi ialah pengambilan data yang diperoleh melalui dokumen-dokumen. Penulis mengumpulkan data dokumen-dokumen internal instansi yang terkait dengan lingkup penelitian diperoleh dari neraca pada Badan Pengelolaan Keuangan Daerah (BPKD) periode 2015-2019. Jenis data penelitian yang digunakan adalah jenis penelitian dekskriptif kuantitatif dengan pendekatan studi kasus yang bertujuan mengetahui Perlakuan Akuntansi Aset serta dokumen-dokumen yang digunakan sehingga memberikan deskripsi atau gambaran. Analisis data ialah kegiatan analisis mengategorikan data untuk mendapatkan pola hubungan tema, menafsirkan apa yang bermakna, serta menyampaikan atau melaporkannnya kepada orang lain yang berminat (Usman, 2017). Metode penelitian yang digunakan penulis adalah metode analisis dekskiptif kuantitatif yaitu dengan metode mengumpulkan data yang sesuai dengan keadaan yang sebenarnya yang bertujuan untuk menyelidiki, menemukan dan memberikan gambaran yang cukup jelas objek yang diteliti kemudian dapat ditarik kesimpulan.

\section{Hasil dan Pembahasan}

\subsection{Hasil Penelitian}

Pencatatan Aset Tetap pada Badan Pengelolaan Keuangan Daerah (BPKD) periode 2015-2019 terdiri dari 7 komponen aset. Berikut daftar jenis Aset tetap Badan Pengelolaan Keuangan Daerah (BPKD) tahun 2015 sampai dengan tahun 2019. 
Baso $\mathbf{R}^{\varpi_{1}}$, Selfiana Bintari ${ }^{2}$, \& Sumarni $S^{3}$

Analisis Perlakuan Akuntansi Aset Tetap pada Badan Pengelolaan Keuangan Daerah (BPKD)

DOI : https://doi.org/10.37531/ecotal.v1i1.6

Tabel 1. Daftar Jenis Aset Tetap BPKD Tahun 2015 - 2019

\begin{tabular}{|c|c|c|c|c|c|c|}
\hline \multirow{2}{*}{$\begin{array}{l}\mathbf{N} \\
\mathbf{o}\end{array}$} & \multirow{2}{*}{$\begin{array}{l}\text { Nama } \\
\text { Bidang } \\
\text { Barang }\end{array}$} & \multicolumn{5}{|c|}{ Jumlah harga barang (dalam rupiah) } \\
\hline & & 2015 & 2016 & 2017 & 2018 & 2019 \\
\hline 1 & Tanah & 0 & 0 & 0 & 0 & 0 \\
\hline 2 & $\begin{array}{l}\text { Peralatan } \\
\text { dan Mesin }\end{array}$ & $\begin{array}{r}7.688 .057 .40 \\
9\end{array}$ & $\begin{array}{r}\text { Rp8.094.810. } \\
109\end{array}$ & $\begin{array}{r}2.596 .889 .9 \\
09\end{array}$ & $\begin{array}{r}3.240 .798 .9 \\
09\end{array}$ & $\begin{array}{r}3.413 .916 .3 \\
60\end{array}$ \\
\hline 3 & $\begin{array}{l}\text { Gedung } \\
\text { dan } \\
\text { Bangunan }\end{array}$ & 0 & 0 & 59.946 .000 & 0 & 0 \\
\hline 4 & $\begin{array}{l}\text { Jalan, } \\
\text { Irigasi, } \\
\text { dan } \\
\text { Jaringan }\end{array}$ & 0 & 0 & 0 & 0 & 0 \\
\hline 5 & $\begin{array}{l}\text { Aset Tetap } \\
\text { Lainnya }\end{array}$ & 0 & 0 & 0 & 0 & 0 \\
\hline 6 & $\begin{array}{l}\text { Konstruks } \\
\text { i Dalam } \\
\text { Pengerjaa } \\
n\end{array}$ & 0 & 0 & 0 & 0 & 0 \\
\hline 7 & $\begin{array}{l}\text { Akumulasi } \\
\text { Penyusuta } \\
\mathrm{n}\end{array}$ & $\begin{array}{r}(6.140 .190 .1 \\
67)\end{array}$ & $\begin{array}{r}(6.836 .704 .7 \\
99)\end{array}$ & $\begin{array}{r}(1.959 .308 .2 \\
50)\end{array}$ & $\begin{array}{r}(2.338 .128 .4 \\
50)\end{array}$ & $\begin{array}{r}(2.667 .189 .8 \\
77)\end{array}$ \\
\hline & $\begin{array}{l}\text { Total Aset } \\
\text { Tetap }\end{array}$ & $\begin{array}{r}1.547 .867 .24 \\
2\end{array}$ & $\begin{array}{r}1.258 .105 .31 \\
0\end{array}$ & 697.527 .658 & 902.670 .458 & 746.726 .482 \\
\hline
\end{tabular}

Berdasarkan tabel di atas menunjukkan bahwa Aset Tetap Badan Pengelolaan Keuangan Daerah (BPKD) Kabupaten Gowa sudah sesuai dengan Pernyataan Standar Akuntansi Pemerintahan (PSAP) 07 terdapat dalam lampiran Peraturan Pemerintahan Nomor 71 Tahun 2010. Semua aset yang bernilai Rp0,00 pada Badan Pengelolaan Keuangan Daerah (BPKD) itu merupakan aset yang pencatatan Asetnya masuk dalam pengakuan Aset Sekertariat Daerah (SEKDA). Kalaupun ada pemeliharaan di mutasikan ke Sekertariat Daerah (SEKDA) untuk penggunaan barang.

Pada Tahun 2016 Total Aset Tetap sebesar Rp1.258.105.310,00. Komponen Aset Tetap Peralatan dan Mesin mengalami peningkatan senilai Rp8.094.810.109,00 dibandingkan Tahun 2015. Sementara Aset Tetap Tanah, Gedung dan bangunan, Jalan, Irigasi, dan Jaringan, Aset Tetap Lainnya, dan Konstruksi Dalam Pengerjaan nilainya RP0,00 artinya bahwa Aset Tetap tersebut bukan merupakan Aset Tetap dari Badan Pengelolaan Keuangan Daerah (BPKD) Kab. Gowa. Pada Tahun 2017 Total Aset Tetap sebesar Rp697.527.658,00. Peningkatan Aset Tetap 
Baso $\mathbf{R}^{\varpi_{1}}$, Selfiana Bintari'2, \& Sumarni $\mathrm{S}^{3}$

Analisis Perlakuan Akuntansi Aset Tetap pada Badan Pengelolaan Keuangan Daerah (BPKD)

DOI : https://doi.org/10.37531/ecotal.v1i1.6

dipengaruhi oleh adanya pemeliharaan Gedung dan Bangunan berupa Sekat Ruangan senilai Rp59.946.000,00. Sementara Aset Tetap Tanah, Jalan, Irigasi, dan Jaringan, Aset Tetap Lainnya, dan Konstruksi Dalam Pengerjaan nilainya RP0,00 artinya bahwa Aset Tetap tersebut bukan merupakan Aset Tetap dari Badan Pengelolaan Keuangan Daerah (BPKD) Kab. Gowa.

Total Aset Tetap pada Tahun 2018 Rp 902.670.458,00. Penurunan nilai Aset Peralatan dan mesin dibandingkan Tahun sebelumnaya senilai Rp3.240.798.909,00. Sementara Aset Tetap Tanah, Gedung dan Bangunan, Jalan, Irigasi, dan Jaringan, Aset Tetap Lainnya, dan Konstruksi Dalam Pengerjaan nilainya RP0,00 artinya bahwa Aset Tetap tersebut bukan merupakan Aset Tetap dari Badan Pengelolaan Keuangan Daerah (BPKD) Kab.Gowa. Terkait dengan nilai Gedung dan Bangunan menjadi Rp0,00 kembali dikarenakan sudah dimutasi dan mengembalikannya ke Sekertariat Daerah (SEKDA). Total Aset Tetap pada Tahun 2019 Rp746.726.482,00. Komponen Aset Tetap Peralatan dan Mesin mengalami peningkatan senilai Rp3.413.916.360,00 dibandingkan Tahun 2018. Sementara Aset Tetap Tanah, Gedung dan bangunan, Jalan, Irigasi, dan Jaringan, Aset Tetap Lainnya, dan Konstruksi Dalam Pengerjaan nilainya RP. 0.00 artinya bahwa Aset Tetap tersebut bukan merupakan Aset Tetap dari Badan Pengelolaan Keuangan Daerah (BPKD) Kab.Gowa.

\section{Pembahasan}

\subsection{Pengakuan Aset Tetap}

Hasil dari perbandingan Pengakuan Aset Tetap pada Badan Pengelolaan Keuangan Daerah (BPKD) sudah sesuai dengan PP Nomor 71 Tahun 2010 (SAP), dimana dalam Peraturan Bupati Nomor 19 Tahun 2019 harus memenuhi kriteria tersebut berwujud dan memiliki masa manfaat lebih dari 12 (dua belas) bulan. Biaya perolehan aset tetap dapat diukur secara andal oleh Pemerintah Daerah dalam mendukung kegiatan operasionalnya dan bukan dimaksudkan untuk diperjualbelikan tetapi diperoleh atau dibangun dengan maksud untuk digunakan. 
Tabel 2. Perbandingan Pengakuan Aset Tetap

\begin{tabular}{|c|c|c|c|}
\hline & PP Nomor 71 Tahun 2010 (SAP) & $\begin{array}{c}\text { Peraturan Bupati Nomor } \\
19 \text { Tahun } 2019 \\
\text { (Kabupaten Gowa) } \\
\end{array}$ & Keterangan \\
\hline & $\begin{array}{l}\text { Untuk dapat diakui sebagai aset } \\
\text { tetap harus dipenuhi kriteria } \\
\text { sebagai berikut: }\end{array}$ & $\begin{array}{l}\text { Untuk dapat diakui } \\
\text { sebagai aset tetap harus } \\
\text { dipenuhi kriteria sebagai } \\
\text { berikut: }\end{array}$ & Sesuai \\
\hline (a) & $\begin{array}{l}\text { Mempunyai masa manfaat lebih (a) } \\
\text { dari } 12 \text { (dua belas) bulan }\end{array}$ & Berwujud; & \\
\hline (b) & $\begin{array}{l}\text { Biaya perolehan aset dapat (b) } \\
\text { diukur secara andal }\end{array}$ & $\begin{array}{l}\text { Mempunyai masa manfaat } \\
\text { lebih dari } 12 \text { (dua belas) } \\
\text { bulan; }\end{array}$ & \\
\hline (c) & $\begin{array}{l}\text { Tidak dimaksudkan untuk dijual (c) } \\
\text { dalam operasi normal entitas }\end{array}$ & $\begin{array}{l}\text { Biaya perolehan aset } \\
\text { dapat diukur secara andal; }\end{array}$ & \\
\hline (d) & $\begin{array}{l}\text { Diperoleh atau dibangun dengan }(\mathrm{d}) \\
\text { maksud untuk digunakan }\end{array}$ & $\begin{array}{l}\text { Tidak dimaksudkan untuk } \\
\text { dijual dalam operasi } \\
\text { normal entitas; } \\
\text { Diperoleh atau dibangun } \\
\text { dengan maksud untuk } \\
\text { digunakan; }\end{array}$ & \\
\hline
\end{tabular}

Pengakuan aset tetap akan dapat diandalkan apabila terdapat bukti bahwa telah terjadi perpindahan hak kepemilikan dan/atau penguasaan secara hukum, misalnya sertifikat tanah dan bukti kepemilikan kendaraan bermotor. Apabila perolehan aset tetap belum didukung dengan bukti secara hukum dikarenakan masih adanya suatu proses administrasi yang diharuskan, seperti pembelian tanah harus diselesaikan proses jual beli (akta) dan sertifikat kepemilikannya di instansi berwenang, maka aset tetap tersebut telah berpindah, misalnya terjadi pembayaran dan penguasaan atas sertifikat tanah atas nama pemilik sebelumnya. Pengakuan Aset Tetap yang berasal dari pengadaan barang dan jasa diperoleh lainnya yang sah, diakui pada saat barang diterima sesuai Berita Acara Penyelesaian Fisik 100\% (PHO) atau dokumen lainnya yang dipersamakan.

\subsubsection{Pengukuran Aset Tetap}

Hasil dari perbandingan Pengukuran Aset Tetap pada Badan Pengelolaan Keuangan Daerah (BPKD) sudah sesuai dengan PP Nomor 71 Tahun 2010 (SAP), dimana dalam Peraturan Bupati Nomor 19 Tahun 2019 Aset tetap yang dinilai dengan biaya perolehan apabila Penilaian Aset 
Baso $\mathbf{R}^{\otimes_{1}}$, Selfiana Bintari'2, \& Sumarni $\mathbf{S}^{3}$

Analisis Perlakuan Akuntansi Aset Tetap pada Badan Pengelolaan Keuangan Daerah (BPKD)

DOI : https://doi.org/10.37531/ecotal.v1i1.6

Tetap dengan menggunakan biaya perolehan tidak memungkinkan maka nilai aset tetap didasarkan pada nilai wajar pada saat perolehan.

Tabel 3. Perbandingan Pengukuran Aset Tetap

\begin{tabular}{|c|c|c|}
\hline PP Nomor 71 Tahun 2010 (SAP) & $\begin{array}{c}\text { Peraturan Bupati Nomor } 19 \\
\text { Tahun } 2019 \text { (Kabupaten Gowa) }\end{array}$ & Keterangan \\
\hline $\begin{array}{l}\text { Aset tetap dinilai dengan harga } \\
\text { perolehan. Apabila penilaian aset } \\
\text { tetap dengan menggunakan biaya } \\
\text { perolehan tidak memungkinkan } \\
\text { maka nilai aset tetap didasarkan pada } \\
\text { nilai wajar pada saat perolehan }\end{array}$ & $\begin{array}{l}\text { Aset tetap dinilai dengan harga } \\
\text { perolehan. Apabila penilaian } \\
\text { aset tetap dengan } \\
\text { menggunakan biaya perolehan } \\
\text { tidak memungkinkan maka nilai } \\
\text { aset tetap didasarkan pada nilai } \\
\text { wajar pada saat perolehan }\end{array}$ & Sesuai \\
\hline $\begin{array}{l}\text { Barang berwujud yang memenuhi } \\
\text { kualifikasi untuk diakui sebagai suatu } \\
\text { aset dan dikelompokkan sebagai aset } \\
\text { tetap, pada awalnya harus diukur } \\
\text { berdasarkan biaya perolehan }\end{array}$ & $\begin{array}{l}\text { Barang berwujud yang } \\
\text { memenuhi kualifikasi untuk } \\
\text { diakui sebagai suatu aset dan } \\
\text { dikelompokkan sebagai aset } \\
\text { tetap, pada awalnya harus } \\
\text { diukur berdasarkan biaya } \\
\text { perolehan }\end{array}$ & Sesuai \\
\hline $\begin{array}{l}\text { Biaya perolehan suatu aset tetap } \\
\text { terdiri dari harga belinya atau } \\
\text { konstruksinya, termasuk bea impor } \\
\text { dan setiap biaya yang dapat } \\
\text { didistribusikan secara langsung } \\
\text { dalam membawa aset tersebut ke } \\
\text { kondisi yang yang membuat aset } \\
\text { tersebut dapat bekerja untuk } \\
\text { penggunaan yang dimaksud. }\end{array}$ & $\begin{array}{l}\text { Biaya perolehan suatu aset } \\
\text { tetap terdiri dari harga belinya } \\
\text { atau konstruksinya, termasuk } \\
\text { bea impor dan setiap biaya } \\
\text { yang dapat didistribusikan } \\
\text { secara langsung dalam } \\
\text { membawa aset tersebut ke } \\
\text { kondisi yang yang membuat } \\
\text { aset tersebut dapat bekerja } \\
\text { untuk penggunaan yang } \\
\text { dimaksud. }\end{array}$ & Sesuai \\
\hline $\begin{array}{l}\text { Jika penyelesaian pengerjaan suatu } \\
\text { aset tetap melebihi dan atau } \\
\text { melewati satu periode tahun } \\
\text { anggaran, maka aset tetap yang } \\
\text { belum selesai tersebut digolongkan } \\
\text { dan dilaporkan sebagai konstruksi } \\
\text { dalam pengerjaan sampai dengan } \\
\text { aset tersebut selesai dan siap dipakai. }\end{array}$ & $\begin{array}{l}\text { Jika penyelesaian pengerjaan } \\
\text { suatu aset tetap melebihi dan } \\
\text { atau melewati satu periode } \\
\text { tahun anggaran, maka aset } \\
\text { tetap yang belum selesai } \\
\text { tersebut digolongkan dan } \\
\text { dilaporkan sebagai konstruksi } \\
\text { dalam pengerjaan sampai } \\
\text { dengan aset tersebut selesai } \\
\text { dan siap dipakai. }\end{array}$ & Sesuai \\
\hline
\end{tabular}




\begin{tabular}{|c|c|c|}
\hline $\begin{array}{l}\text { Biaya perolehan dari masing-masing } \\
\text { aset tetap yang diperoleh secara } \\
\text { gabungan ditentukan dengan } \\
\text { mengalokasikan harga gabungan } \\
\text { tersebut berdasarkan perbandingan } \\
\text { nilai wajar masing-masing aset yang } \\
\text { bersangkutan. }\end{array}$ & $\begin{array}{lrr}\text { Biaya perolehan dari masing- } \\
\text { masing aset tetap yang } \\
\text { diperoleh secara gabungan } \\
\text { ditentukan } & \text { dengan } \\
\text { mengalokasikan } & \text { harga } \\
\text { gabungan tersebut berdasarkan } \\
\text { perbandingan nilai } r \text { wajar } \\
\text { masing-masing aset } \\
\text { bersangkutan. }\end{array}$ & Sesuai \\
\hline $\begin{array}{l}\text { Suatu aset tetap dapat diperoleh } \\
\text { melalui pertukaran sebagian aset } \\
\text { tetap yang tidak serupa atau aset } \\
\text { tetap lainnya. Biaya dari pos } \\
\text { semacam itu diukur berdasarkan nilai } \\
\text { wajar aset yang diperoleh yaitu nilai } \\
\text { ekuivalen atas nilai tercatat aset yang } \\
\text { dilepas setelah disesuaikan dengan } \\
\text { jumlah setiap kas atau setara kas } \\
\text { yang ditransfer/diserahkan. }\end{array}$ & $\begin{array}{l}\text { Suatu aset tetap dapat } \\
\text { diperoleh melalui pertukaran } \\
\text { sebagian aset tetap yang tidak } \\
\text { serupa atau aset tetap lainnya. } \\
\text { Biaya dari pos semacam itu } \\
\text { diukur berdasarkan nilai wajar } \\
\text { aset yang diperoleh yaitu nilai } \\
\text { ekuivalen atas nilai tercatat aset } \\
\text { yang dilepas setelah } \\
\text { disesuaikan dengan jumlah } \\
\text { setiap kas atau setara kas yang } \\
\text { ditransfer/diserahkan. }\end{array}$ & $\mathrm{Se}$ \\
\hline $\begin{array}{l}\text { Aset tetap yang diperoleh dari } \\
\text { sumbangan (donasi) harus dicatat } \\
\text { sebesar nilai wajar pada saat } \\
\text { perolehan. }\end{array}$ & $\begin{array}{l}\text { Aset tetap yang diperoleh dari } \\
\text { sumbangan (donasi) harus } \\
\text { dicatat sebesar nilai wajar pada } \\
\text { saat perolehan. }\end{array}$ & $\mathrm{Se}$ \\
\hline
\end{tabular}

Pengukuran aset tetap harus memperhatikan kebijakan tentang ketentuan nilai satuan minimum kapitalisasi aset tetap. Jika nilai perolehan aset tetap dibawah nilai satuan minimum kapitalisasi maka atas aset tetap tersebut tidak dapat diakui dan disajikan sebagai aset tetap. Aset-aset tersebut diperlakukan sebagai aset lainnya. Konstruksi dalam pengerjaan yang sudah selesai dibuat atau dibangun dan telah siap dipakai harus segera direklasifikasikan ke salah satu akun yang sesuai dengan pos aset tetap.

Biaya perolehan suatu aset tetap terdiri dari harga barang atau konstruksinya, termasuk bea impor dan setiap biaya yang dapat distribusikan secara langsung dalam membawa aset tersebut ke kondisi yang membuat aset tersebut dapat bekerja untuk penggunaan yang dimaksudkan. Suatu aset tetap dapat dilepas dalam pertukaran dengan kepemilikannya aset yang serupa, tidak ada keuntungan dan kerugian yang diakui didalam transaksi ini. Biaya aset yang baru diperoleh dicatat sebesar nilai tercatat (carrying amount) atas aset yang lepas. Aset tetap yang diperoleh dari sumbangan (donasi) harus dicatat sebesar nilai wajar pada saat perolehan. Jadi, sumbangan 
Baso $\mathbf{R}^{\otimes_{1}}$, Selfiana Bintari'2, \& Sumarni $\mathbf{S}^{3}$

Analisis Perlakuan Akuntansi Aset Tetap pada Badan Pengelolaan Keuangan Daerah (BPKD)

DOI : https://doi.org/10.37531/ecotal.v1i1.6

aset tetap didefenisikan sebagai transfer tanpa persyaratan suatu aset tetap ke satu entitas, misalnya perusahaan nonpemerintah memberikan bangunan yang dimilikanya untuk digunakan oleh satu unit Pemerintah Daerah tanpa persyaratan apapun. Penyerahan aset tetap tersebut akan sangat andal bila didukung dengan bukti perpindahan kepemilikannya secra hukum, seperti adanya akta hibah.

\subsubsection{Pengeluaran Setelah Perolehan Aset Tetap}

Hasil dari perbandingan pengeluaran setelah perolehan Aset Tetap pada Badan Pengelolaan Keuangan Daerah (BPKD) sudah sesuai dengan PP Nomor 71 Tahun 2010 (SAP), dimana dalam Peraturan Bupati Nomor 19 Tahun 2019 Aset tetap. Pengeluaran setelah perolehan aset tetap awal suatu aset tetap yang memperpanjang masa manfaat atau yang kemungkinan besar memberi masa manfaat ekonomik dimasa yang akan datang dalam bentuk kapasitas, mutu produksi, atau peningkatan standar kinerja, dan memenuhi nilai Batasan kapitalisasi harus ditambahkan pada nilai tercatat aset yang bersangkutan. Pengeluaran belanja untuk aset tetap setelah perolehan dapat dibedakan menjadi dua, yaitu belanja untuk pemeliharaan dan belanja untuk peningkatan.

Tabel 4. Perbandingan Pengeluaran Setelah Perolehan Aset Tetap

\begin{tabular}{|c|c|c|}
\hline PP Nomor 71 Tahun 2010 (SAP) & $\begin{array}{c}\text { Peraturan Bupati Nomor } 19 \text { Tahun } \\
2019 \text { (Kabupaten Gowa) }\end{array}$ & Keterangan \\
\hline $\begin{array}{l}\text { Pengeluaran setelah perolehan } \\
\text { awal suatu aset tetap yang } \\
\text { memperpanjang masa manfaat } \\
\text { atau kemungkinan besar } \\
\text { memberi manfaat ekonomik } \\
\text { dimasa yang akan datang dalam } \\
\text { bentuk kapasitas, mutu } \\
\text { produksi, atau peningkatan } \\
\text { standar kinerja, harus } \\
\text { ditambahkan pada nilai tercatat } \\
\text { aset yang bersangkutan. }\end{array}$ & $\begin{array}{l}\text { Pengeluaran setelah perolehan awal } \\
\text { suatu aset tetap yang memperpanjang } \\
\text { masa manfaat atau kemungkinan besar } \\
\text { memberi manfaat ekonomik dimasa } \\
\text { yang akan datang dalam bentuk } \\
\text { kapasitas, mutu produksi, atau } \\
\text { peningkatan standar kinerja, harus } \\
\text { ditambahkan pada nilai tercatat aset } \\
\text { yang bersangkutan. Pengeluaran } \\
\text { dimaksud adalah pengeluaran yang } \\
\text { dapat dikelompokkan dalam } \\
\text { pengeluaran modal } \\
\text { expenditure). }\end{array}$ & $\begin{array}{c}\text { Sesuai } \\
\text { dengan SAP } \\
\text { tapi } \\
\text { dipertegas } \\
\text { dengan } \\
\text { pengeluaran } \\
\text { yang } \\
\text { dimaksud } \\
\text { adalah } \\
\text { capital } \\
\text { expenditure }\end{array}$ \\
\hline
\end{tabular}

Belanja untuk pemeliharaan dimaksudkan untuk mempertahankan kondisi aset tetap tersebut sesuai dengan kondisi normal. Sedangkan belanja untuk peningkatan adalah belanja yang 
Baso $\mathbf{R}^{\otimes_{1}}$, Selfiana Bintari'2, \& Sumarni $\mathbf{S}^{3}$

Analisis Perlakuan Akuntansi Aset Tetap pada Badan Pengelolaan Keuangan Daerah (BPKD)

DOI : https://doi.org/10.37531/ecotal.v1i1.6

memberi manfaat ekonomi dimasa yang akan datang dalam bentuk peningkatan kapasitas, masa manfaat, mutu produksi, atau peningkatan standar kinerja.

Kebijakan batas minimum kapasitas hanya diberlakukan untuk jenis belanja peralatan/mesin dan sebagian aset tetap lainnya sedangkan Batasan minimum untuk tanah, bangunan dan gedung, jalan, irigasi, dan jaringan, serta aset tetap lainnya berupa koleksi perpustakaan dan barang bercorak kesenian tidak dibatasi berapapun besarannya. Batasan ini hanya untuk perolehan awal aset tetap melalui pembelian aset tetap atau pembangunan baru yang tidak terkait dengan aset tetap yang telah ada.

\subsubsection{Pengukuran Berikutnya Terhadap Pengakuan Awal}

Hasil dari perbandingan pengukuran berikutnya erhadap pengakuan awal pada Badan Pengelolaan Keuangan Daerah (BPKD) sudah sesuai dengan PP Nomor 71 Tahun 2010 (SAP), dimana dalam Peraturan Bupati Nomor 19 Tahun 2019 Aset tetap. Aset tetap disajikan berdasarkan biaya perolehan aset tetap tersebut dikurangi akumulasi penyusutan. Dimana metode penyusutan yang digunakan harus dapat menggambarkan manfaat ekonomi atau kemungkinan jasa (service potential) yang akan mengalir ke pemerintah.

Pengukuran Berikutnya Terhadap Pengakuan Awal

\begin{tabular}{llll}
\hline PP Nomor 71 Tahun 2010 (SAP) & $\begin{array}{l}\text { Peraturan Bupati Nomor 19 Tahun } \\
2019 \text { (Kabupaten Gowa) }\end{array}$ & Keterangan \\
\hline Aset tetap disajikan berdasarkan biaya & Aset tetap disajikan berdasarkan & Sesuai \\
perolehan aset tetap tersebut & biaya perolehan aset tetap & \\
dikurangi akumulasi penyusutan. & tersebut dikurangi akumulasi & \\
Apabila terjadi kondisi yang & penyusutan. Apabila terjadi & \\
memungkinkan penilaian kembali, & kondisi yang memungkinkan & \\
maka aset tetap akan disajikan dengan & penilaian kembali, maka aset tetap & \\
penyusuaian pada masing-masing & akan disajikan dengan & \\
akun aset tetap dan akun & penyusuaian pada masing-masing & \\
diinvestasikan dalam aset tetap. & akun aset tetap dan akun & \\
& diinvestasikan dalam aset tetap. & \\
\hline
\end{tabular}


Masa manfaat aset tetap yang dapat disusutkan harus ditinjau secara periodik dan jika terdapat perbedaan besar dari estimasi sebelumnya, penyusutan periode sekarang dan yang akan datang harus dilakukan penyesuaian.
Masa manfaat aset tetap yang dapat disusutkan harus ditinjau secara periodik dan jika terdapat perbedaan besar dari estimasi sebelumnya, penyusutan periode sekarang dan yang akan datang harus dilakukan penyesuaian.

Sesuai

\begin{tabular}{|c|c|c|}
\hline $\begin{array}{l}\text { Metode penyusutan yang dapat } \\
\text { dipergunakan antara lain: } \\
\text { (a) Metode Garis Lurus (straighy } \\
\text { line method) } \\
\text { (b) Metode Saldo Menurun Ganda } \\
\text { (double declining balance } \\
\text { method) } \\
\text { (c) Metode Unit Produksi (unit of } \\
\text { production method) }\end{array}$ & $\begin{array}{l}\text { Metode penyusutan } \text { yang } \\
\text { digunakan adalah metode garis } \\
\text { lurus (straight line method), } \\
\text { dimana tarif/besarnya } \\
\text { penyusutan selalu sama setiap } \\
\text { periode selama umur ekonomis } \\
\text { untuk seluruh jenis aset tetap } \\
\text { yang dimiliki selain tanah dan aset } \\
\text { tetap lainnya seperti tanaman dan } \\
\text { hewan serta konstruksi dalam } \\
\text { pengerjaan. }\end{array}$ & $\begin{array}{l}\text { Pada Perbu } \\
\text { Gowa No } \\
19 \text { tahun } \\
2019 \\
\text { metode } \\
\text { penyusutan } \\
\text { yang } \\
\text { digunakan } \\
\text { adalah }\end{array}$ \\
\hline
\end{tabular}

Aset tetap merupakan komponen aset operasi pemerintah yang penting dalam menjalankan operasional pemerintah dan rentan terhadap penurunan kapasitas sejalan dengan penggunaan dan pemanfaatannya. Penyusuaian nilai sehubung dengan penurunan kapasitas dan manfaat dari suatu aset tersebut, maka diterapkan masa manfaat dari masing-masing kelompok aset tetap. Penyusutan adalah alokasi yang sistematis atas nilai suatu aset tetap yang dapat disusutkan selama masa manfaat yang yang bersangkutan.

Penyusutan aset tetap diakui dengan nilai penyusutan untuk masing-masing periode dan diakui sebagai pengurangan nilai tercatat aset tetap dalam neraca dan beban penyusutan dalam laporan operasional. Metode penyusutan yang digunakan adalah metode garis lurus (straight line method), dimana tarif/besarnya penyusutan selalu sama setiap periode selama umur ekonomis untuk seluruh jenis aset tetap yang dimiliki selain tanah dan aset tetap lainnya seperti tanaman dan hewan serta konstruksi dalam pengerjaan. Perhitungan penyusutan, dihitung secara bulanan yaitu perolehan aset tetap dihitun beradasarkan pada bulan dimana aset tetap tersebut diperoleh.

\subsubsection{Penghentian dan Pelepasan}

Hasil dari perbandingan Penghentian dan Pelepasan pada Badan Pengelolaan Keuangan Daerah (BPKD) sudah sesuai dengan PP Nomor 71 Tahun 2010 (SAP), dimana dalam Peraturan Bupati 
Baso $\mathbf{R}^{\otimes_{1}}$, Selfiana Bintari'2, \& Sumarni $\mathbf{S}^{3}$

Analisis Perlakuan Akuntansi Aset Tetap pada Badan Pengelolaan Keuangan Daerah (BPKD)

DOI : https://doi.org/10.37531/ecotal.v1i1.6

Nomor 19 Tahun 2019 Aset tetap. Aset tetap yang secara permanen dihentikan atau dilepas harus dieliminasi dari neraca dan diungkapkan dalam Catatan atas Laporan Keuangan (CaLK).

Penghentian dan pelepasan aset tetap didasarkan pada peraturan perundang-undangan.

Perbandingan Penghentian dan Pelepasan

\begin{tabular}{|c|c|c|}
\hline PP Nomor 71 Tahun 2010 (SAP) & $\begin{array}{c}\text { Peraturan Bupati Nomor } 19 \\
\text { Tahun } 2019 \text { (Kabupaten } \\
\text { Gowa) } \\
\end{array}$ & Keterangan \\
\hline $\begin{array}{l}\text { Suatu aset tetap dieliminasi dari } \\
\text { neraca ketika dilepaskan atau bila aset } \\
\text { secara permanen dihentikan } \\
\text { penggunaannya dan tidak ada manfaat } \\
\text { ekonomik masa yang akan datang. }\end{array}$ & $\begin{array}{l}\text { Suatu aset tetap dieliminasi } \\
\text { dari neraca ketika dilepaskan } \\
\text { atau bila aset secara } \\
\text { permanen dihentikan } \\
\text { penggunaannya dan tidak ada } \\
\text { manfaat ekonomik masa yang } \\
\text { akan datang. Eliminasi aset } \\
\text { tetap tersebut didasarkan } \\
\text { pada tanggal transaksi yang } \\
\text { terasa pada dokumen bukti } \\
\text { pendukung. }\end{array}$ & Sesuai \\
\hline $\begin{array}{lccr}\text { Aset tetap } & \text { yang } & \text { secara permanen } \\
\text { dihentikan } & \text { atau } & \text { dilepas } & \text { harus } \\
\text { dieliminasi } & \text { dari } & \text { neraca } & \text { dan } \\
\text { diungkapkan } & \text { dalam } & \text { Catatan } & \text { atas } \\
\text { Laporan Keuangan } & & \\
\end{array}$ & $\begin{array}{l}\text { Aset tetap yang secara } \\
\text { permanen dihentikan atau } \\
\text { dilepas harus dieliminasi dari } \\
\text { neraca dan diungkapkan } \\
\text { dalam Catatan atas Laporan } \\
\text { Keuangan }\end{array}$ & Sesuai \\
\hline $\begin{array}{l}\text { Aset tetap yang dihentikan dari } \\
\text { penggunaan aktif pemerintah tidak } \\
\text { memenuhi defenisi aset tetap dan } \\
\text { harus dipindahkan ke pos aset lainnya } \\
\text { sesuai dengan nilai tercatatnya }\end{array}$ & $\begin{array}{l}\text { Aset tetap yang dihentikan } \\
\text { dari penggunaan aktif } \\
\text { pemerintah tidak memenuhi } \\
\text { defenisi aset tetap dan harus } \\
\text { dipindahkan ke pos aset } \\
\text { lainnya sesuai dengan nilai } \\
\text { tercatatnya }\end{array}$ & Sesuai \\
\hline
\end{tabular}

Aset-aset yang dihentikan dari pengunaan aktif pemerintah daerah, maka aset tetap tersebut direklasikasi dalam kelompok aset lainnya. Suatu aset tetap dilepaskan atau dihentikan secara permanen setelah mendapatkan persetujua penghapusan sesuai ketentuan yang berlaku, maka aset tetap tersebut dieliminasi dari neraca. Beberapa keadaan dan alasan penghentian aset tetap antara lain adalah dihibahkan, dipertukarkan dengan aset tetap lainnya, Dijadikan penyertaan modal, dijual dan dimusnahkan. 
Baso $\mathbf{R}^{\otimes_{1}}$, Selfiana Bintari'2, \& Sumarni $\mathbf{S}^{3}$

Analisis Perlakuan Akuntansi Aset Tetap pada Badan Pengelolaan Keuangan Daerah (BPKD)

DOI : https://doi.org/10.37531/ecotal.v1i1.6

\section{Kesimpulan}

Perlakuan akuntansi aset tetap pada Badan Pengelolaan Keuangan Daerah terdiri daripengakuan aset tetap, pengukuran aset tetap, pengeluaran setelah perolehan, pengukuran berikutnya terhadap penilaian awal, penghentian dan pelepasan, serta pengungkapan aset tetap. Perlakuan akuntansi aset tetap pada Badan Pengeloaan Keuangan Daerah (BPKD) berpedoman pada Peraturan Pemerintah Nomor 71 Tahun 2010 serta Peraturan Bupati Nomor 19 Tahun 2019. Artinya bahwa semua perlakuan aset tetap yang diterapkan sesuai dengan peraturan perundang-undangan yang berlaku. Aset tetap yang tercantum di dalam Neraca Badan Pengelolaan Keuangan Daerah (BPKD) pada tahun 2015 sampai dengan tahun 2019 sudah sesuai dengan Standar Akuntansi Pemerintah (PSAP No. 07 Tentang Akuntansi Aset Tetap).

\section{Referensi :}

Anastasia, Maria (2017). Analisis Perlakuan Akuntansi Aset tetap pada CV. Kruwing Indah Kabupaten Hulu Sungai Utara. Sekolah Tinggi Ilmu Ekonomi Pancasetia Banjarmasin Jl. Ahmad Yani Km 5,5 Banjarmasin, Kalimantan Selatan.

Caronila, Manassoh H. (2019). Analisis perlakuan akuntansi aset tetap pada Badan Pengelola Keuangan dan Barang Milik Daerah Kota. Jurusan Akuntansi Fakultas Ekonomi dan Bisnis Universitas Sam Ratulangi Jl. Kampus UNSRAT Manado, Indonesia.

Erlina, dkk (2017) Akuntansi Keuangan Daerah Berbasis Akrual.Salemba Empat. Jakarta Selatan Fariansyah, Moh Affandy., Faridah., dkk (2018). Analisis Perlakuan Akuntansi Aset Tetap pada BPJS Kesehatan Cabang Makassar. Fakultas Ekonomi Jurusan Akuntansi Universitas Bosowa. Makassar.

Chandrarin, Grahita (2017) Metode Riset Akuntansi. Salemba Empat.Jakarta Selatan

Ikatan Akuntansi Indonesia. (2014). Standar Akuntansi Pemerintahan Permen RI No. 71 Tahun 2010. Jakarta. Visi media.

Kieso, Donald E. Weygandt, Jerry J., (2018). Akuntansi Keuangan Menengah - Intermediate Accounting. Edisi IFRS. Jakarta. Salemba Empat.

Mahmudi, (2016). Analisis Laporan Keuangan Pemerintah Daerah. Yogyakarta. Sekolah Tinggi Ilmu Manajemen YKPN

Mararu Gandi, Sondakh Julie. (2019). Analisis Perlakuan Akuntansi Aset Tetap Pada Perusahaan Umum Badan Logistik Divisi Regional Provinsi Sulawesi Utara dan Gorontalo. Fakultas Ekonomi dan Bisnis.

Masipuang, Yefta, Ilat, Ventja. (2015). Analisis Perlakuan Akuntansi Aset Tetap Pada Badan Kepegawaian dan Diklat BKD Kota Manado.Akuntansi. Gorontalo.

Rahayu Purnaningsih \& Pustikaningsih Adeng (2019). Analisis Perlakuan Akuntansi Aset Tetap Pada Organisasi Nirlaba. Prodi Akuntansi, Universitas Negeri Yogyakarta.

Reeve, James.R. (2013). Pengantar Akuntansi Adaptasi Indonesia. Buku 2. Jakarta. Salemba Empat.

Rusmana, Oman, Setyaningrum, Dyah.(2017). Akuntansi Pemerintahan Daerah. Jakarta. Salemba Empat. 
Rusman (2018). Analisis Perlakuan Aset Tetap Pada Pemerintahan Aceh. Provinsi Aceh.

Safitri, Rizkie S.I dan Rahayu Yuliastuti. (2017). Analisis Perlakuan Akuntansi Aset Tetap Berdasarkan PSAP No.07.Sekolah Tinggi Ilmu Ekonomi Indonesia (STIESIA) Surabaya Masipuang Yefta, Ilat Ventje, dkk (2015). Analisis Perlakuan Akuntansi Aset Tetap Pada Badan Kepegawaian dan Diklat BKD Kota Manado. Akuntansi. Gorontalo.

Sita, Shella Iko, Irmadariyani Ririn. (2017). Analisis Perlakuan Akuntansi Aset Tetap Pada Rumah Sakit Umum Daerah Genteng. Fakultas Ekonomi, Universitas Jember (UNEJ) Jln. Kalimantan 37, Jember.

Sugiyono. (2010). Sampel adalah bagian dari jumlah dan karakteristik yang dimiliki oleh populasi tersebut.

Suryabrataa Sumandi (2003). Metodologi Penelitian. Universitas Gadjah Mada. Jakarta

Tipan, Akhyar, Saerang David P.E. (2015). Analisis Perlakuan Akuntansi Aset Tetap Pada Dinas Pekerjaan Umum (PU) Provinsi Sulawesi Utara. Fakultas Ekonom Ni dan Bisnis Jurusan Ekonomi Universitas Sam Ratulangi Manado.

Usman H. , Akbar P. (2017). Metodologi Penelitian Sosial. Bumi Askara. Jakarta

Peraturan Bupati Nomor 19 Tahun (2019). Tentang Kebijakan Akuntansi Pemerintah Daerah Kabupaten Gowa. 